Global Conferences Series:

Social Sciences, Education and Humanities (GCSSSEH), Volume 3, 2019

The $1^{\text {st }}$ International Conference on Education, Social Sciences and Humanities

DOI: https://doi.org/10.326/hum0201

\title{
How Instructors Conducted English Teaching as Foreign Language for Visual Disability Learners
}

\author{
Abd. Halim ${ }^{1}$ Hariyanto $^{2}$ Nurhidayah ${ }^{3}$ \\ ${ }^{123}$ Universitas Negeri Makassar \\ abdhalimmhum@yahoo.com
}

\begin{abstract}
This qualitative study aimed to explore English teaching strategy by the professional English instructors and their belief on selecting the strategy. Three instructors and students from two classes of SLBA YAPTI MAKASSAR were observed and interviewed. The strategy implemented was an eclectic method mingling the Grammar Translation (GT) and Audio Lingual (AL) equipped with computer applications. GT was purposefully applied for obtaining the basic language competence. Words and pronunciation were firstly introduced. All the learned words were repeatedly pronounced and followed by spelling exercise as a word memorizing process. To introduce the meaning was done by: (a) direct touch to the objects either real or artificial, and followed by the equivalent translation to deeply memorize the words, or (b) Meldict usage, a digital dictionary application. The word was rehearsed and practiced by translating English phrases or sentences into Indonesian or vice versa. AL strategy was expected to develop the language skills by computer application NVDA (screen reader) by which letters, words, sentences or stories can be pronounced and replayed by the instructors. The instructors and students believed that integrated use of strategies like GT and AL and electronic instruments is an effective strategy for visual disability.
\end{abstract}

Keywords: visual disability, grammar translation, audio lingual, digital dictionary and integrated

\section{Introduction}

Since the reformation era in Indonesia and the worldwide expansion of English as a consequence of globalization there has been increasing interest in the disability student education both for physical and mental defect. The spirit of human right has been absorbed that any human has to be served equally in educational aspect despite of physical and mental disability. Furthermore, the constitution on national education No. 20 of 2003 clearly asserts that any citizen deserves to receive qualified education including physically defective and mentally retarded children. Therefore, opportunity is widely facilitated to any disability to get their education at school or department based on the need and degree of disability. In

Copyright () 2019, the Authors. Published by Redwhite Press.

Page | 86

This is an open access article under the CC BY-NC license

(http://creativecommons.org/licenses/by-nc/4.0). 
Indonesian education system, special education is schooling for learners who have physical or mental defect so that they need a special treatment in the learning process as long as they are empirically detected to have a potential intelligence and special talent.

One type of disability is visual defect both total absence of sight or low vision. In Makassar, there is a special school that accommodates the special needs of visual impairment students. There are three grades, i.e. elementary school, junior and senior high schools. The school is named SLBA YAPTI Makassar. This article will explore some of the issues and complexities of teaching and learning English for visually disable learners regarding what teaching strategies used by the professional English instructors and what the learners expected the instructors to do with the teaching.

Erfan Soleimani Sefat et al (2016) who have studied the needs and problems of students with visual impairment reported that service improvement for people with visual impairment relevant to the adaptation of services to their needs pave the ground to build, reduce poverty and enhance the quality of life.

The learners with visual disability call for extra treatment in learning if compared to the sighted ones. Therefore to achieve the learning objectives in the curriculum, the instructors have to accommodate the learners' learning needs. They have complex needs since they easily get visual fatigue when they are attempting to learn (Davis: 2003). Even some researchers purported that reading in Braille by blind children impose more cognitive ability rather than that of by sighted children when reading printed material. Therefore, they need more bodily movement and sound awareness to stimulate their classroom activeness and concentration.

English education for visual impairment as a matter of fact requires a special treatment not only from the instructors but also from government or parents. The learners as citizen by that way may become independent and productive. The instructors in teaching must engage varied teaching strategies that fit the learners' needs. They must be aware that the learners have physical limitation. The process of teaching should be emphasized on what they can touch and listen to the language. Therefore, to be effective instructors they need sufficient knowledge and skill ranging from content knowledge, pedagogical knowledge and knowledge of how the learners with visual disability learn in different settings. The decisions on English teaching taken by the instructors should be relevant to and sustain the principles of second language learning (Cochran-Smith \& Zeichner, 2005; Darling-Hammond \& Bransford, 2005. Therefore, the instructors in the school for visual disability encounter a great deal of challenges. So the questionable points in this study what learning strategies are used by the instructors and why they believed to be the effective ways.

\section{Method}

This study is a qualitative research. It is designed to explore English teaching strategy by the professional English instructors and their belief on selecting the strategy. Three instructors and 10 students from two classes of SLBA YAPTI MAKASSAR were observed and interviewed.

\section{Results and Discussion}

Most present teaching of English vastly engages technological devices. The emergence of personal computer or multimedia equipped with applications has increasingly changed the way of how the instructors conducted their class. The class without technological devices seems to be left behind because the devices facilitate and stimulate classroom interaction and learning. The instructors in SLBA YAPTI Makassar also utilize personal computer or laptop and computer applications for English teaching. Listening activities were conducted by the instructors to develop the language skills of the learners by computer application NVDA (screen reader) by which letters, words, sentences or stories can be 
pronounced by using the application. This fact arouses the researcher's interest to explore the instructors' best practices in conducting teaching English for visual disability.

Based on the classroom observation and dept-interview nine main types of teaching activities were identified. In general, the activities consist of audio lingual and grammar translation method equipped with computer applications. Listening as the first and basic skill in the process of second language acquisition was conducted in a relaxed atmosphere. The instructor introduced the listening material by telling them the topic, setting and characters in the story. The listening may be carried out by the instructor orally or by using laptop, loudspeakers. Salisbury (2008: 95) stated that material presented orally is helpful for learners with visual disability.

Reading the text in Braille was a specific skill by visual impairment. The learners were instructed to read and to be integrated with listening. The instructor used particular strategy to train the students' reading skill by Braille. Carney, et al. (2003: 47) defined that Braille is an embossed symbolic system read tactually. While touching the writing form, the learners barked the text. They thereby integrated the skills.

Translating has boost up the learners to use their cognitive ability like word, phrase and sentence translation since it involves a bilingual competence. They translated the text by using Meldict, a digital dictionary pronouncing instead of writing the words. By translating, the learners are expected to detect and use the grammatical aspects such as word order, singular and plural form, time signal etc., and to develop word knowledge. Most learners felt free to find out the meanings of words, and write their own phrase or sentences by Braille. It included analyzing noun and verb in the sentences based on the learners' assignment. Although the learners are visual impairment, the instructor tried to make the students understand the word classes. He realized that the learners should be taught English not only speaking but also writing and grammar.

Question and answer activity as a kind of language drill was also conducted by the instructor in the class. Teaching numerical subject matter for example, the instructor asked the learners orally and they responded orally too. The activity was intended to encourage the spontaneous response from the learners. He asked them one by one. Sometimes he just asked yes-no questions or simple question so they may respond quickly, for example,. "How many pens do you have?," "I have two pens" or "two", etc,. This activity was conducted by the instructor in a relaxed situation so that the learners felt free.

The next common activity was speaking by using NVDA software to pronounce the words. The instructor utilized the screen reader to assist the learners pronounce the words correctly. In this activity they typed the words or sentences in their laptop and turned the screen reader, after that they followed the screen reader's sound. The screen reader was one of the media that was (2008: 97) suggested by Salisbury. He argued that the student who was unable to access computer visually may get benefit from speech output by this way. NVDA application can read loudly any text presented on the screen. The learners could practice how to pronounce correctly the words or sentences. They could repeat to read the sentences through repetition drill. This activity was sometimes followed by writing practice by Braille. So, listening was integrated with speaking and writing using riglet and pen. In fact, the instructor had applied the techniques in different class, but in the ninth grade, he tried to teach listening by using NVDA, and he asked the learners to write by Braille of what they listened.

Using new words into sentences was performed through a technological application, Meldict. In relation to this, Salisbury (2008: 97) declared that the technology includes adaptive hardware or software to make the word easily accessible. It is specifically designed to be used by people with visual impairment. It can be used to access information or complete tasks. In applying this strategy, the 
instructor asked the learners to apply the words which they had known in the sentences and when they want to ask something to their friends in the class. For example, when the learners want to borrow something, they have to say in English. That is one of the teacher's strategies. By this way, they always remember the words.

The instructor always asked the learners the meaning of the words that they listened. He also asked them to pronounce the words one by one to make him sure that they were able to write the words in the right ways. He frequently trained them to differentiate the spelling of A, E, I, N, M, G, J, T, D in English. After he played the first paragraph of the reading passage, he asked them to check their Braille. The teacher made it sure that all of them listened and wrote in the right Braille form.

Game was one of the strategies used by the instructor in teaching English. It was matching card. The instructor applied the game strategy to make the students easier understand the teaching material. At the time, she made the learning process be fun by playing the game. The name of game is Match a card. It is one of teacher's strategies on how to memorize the words in pleasing way. When the teacher applied this strategy the students look so excited and happy. This strategy trains them how to remember, read by using Braille, and work together in same time although they have a limited vision. Game also was a kind of techniques suggested by Salisbury (2008:95). He argued that many pupils with visual impairment have well developed memory skills and team games can take advantage of games.

Teaching procedure is another thing that is important to be discussed. Based on the observation the instructor started his class by greeting the learners in English and he begged the learners to pray as an opening ceremony. He asked the students to take their books or notes and then he reviewed the last material or subject matter to refresh the students' memory so they can rehearse and recognize the last topic. He explained the new topic emphasizing on speaking and listening because he would not use the whiteboard and he could not use projector for them. The instructor had to teach the learners orally. However, by the help of technology it was still possible for the instructor to teach the four language skills. For reading activity, the learners used and read the text by Braille. Also the instructor taught them to write by using special tools for producing Braille, namely: pen and riglet. At the end of the class he always gave assignment or homework to the them. He asked the learners to do it individually or by group. He also asked them to make a summary, and checked them whether they understand the lesson or not. Also he gave them suggestion and advice.

\section{Conclusions}

The instructor really realized that the English learners with visual impairment were limited in their vision and sometimes had low learning motivation. So, he would not force his student to finish or do so many tasks. The student did his task in laptop. To pronounce the words, the teacher asked the student to turn on the screen reader application. The teacher asked the student to use NVDA. NVDA is the screen reader application which is designed special for visual impairment people. The teacher taught the student to speak up using screen reader so he could mention the word with the right pronunciation.

\section{Acknowledgement}

I would like to express my gratitude to the headmaster, the instructors and the participated students SLBA YAPTI MAKASSAR

\section{References}

Farrell, M. (2008). Educating Special Children: An Introduction to Provision for Pupils with Disabilities and Disorders. New York: Routledge.

Fauziati, E. (2002). Teaching English as a Foreign Language. Surabaya: Muhammadiyah University Press. 
RedWhite. ${ }^{\text {ress }}$ Giobal Conferencees Series: Social Sciences, Edcuation and Humanities (GCSSSEH), Volume 3, 2019

Hammond, D. L., Austin, K., Orcutt, S., \& Rosso, J. (2001). How People Learn: Introduction to Learning Theories. San Francisco: Stanford University.

Hill, H. L. (2014). Adult Learning. Graduate Students' Perspectives on Effective Teaching. (Online). (http://www.winchester.ac.uk/Studyhere/ExcellenceinLearningandTeaching/research/ejournals/Documents/Effective\%20feedback\%20The\%20student\%20perspective.pdf, Retrieved on July, 20 th 2016).

Jordan, A., Carlile, O., \& Stack, A. (Eds.), (2008). Approaches to Learning: a Guide for Teachers. New York: Open University Press.

Kuna, D. $6^{\text {th }}$ October (2014). Teaching Students with Visual Impairments. Strategies for Teaching Students with Vision Impairments, (Online), (http://www.as.wvu.edu/ scidis/vision.html\#sect2, Retrieved on September, $16^{\text {th }}$ 2015).

Koeswiryono, P. D. (2013). The Teaching and Learning Process of Reading Comprehension to Students with Visual Impairment (a Descriptive Research at the Seventh and Eighth Grade of SMP YKAB Surakarta). Unpublished Thesis. Surakarta, Teacher Training and Education Faculty: Sebelas Maret University.

Prasetyaningsih, W. I. (2011). A Descriptive Study of the English Teaching aand Learning Process of Children with Visual Impairment in Second Grade of Junior High School at SLB A YAAT Klaten in Academic Year 2009/2010. Unpublished Thesis. Surakarta, Teacher Training and Education Faculty: Sebelas Maret University.

Sacks, Z. S., \& Wolffe, E. K. (Eds.), (2006). Teaching Social Skills to Students with Visual Impairments: from Theory to Practice. New York: American Foundation for the Blind Press.

Salisbury, R. (2008). Teaching Pupils with Visual Impairment: A Guide to Making the School Curriculum Accessible. New York: Routledge.

Silverstone, B. D. S., Lang, A. M., Rosenthal, P. B., \& Faye, E. E. (2000). The Lighthouse Handbook on Vision Impairment and Vision Rehabilitation. New York: Oxford UniversityPress 